\title{
Darwin's Busts and Public Evolutionary Outreach and Education
}

\author{
Sidney Horenstein
}

Published online: 9 July 2011

(C) Springer Science+Business Media, LLC 2011

\begin{abstract}
For the 1909 Darwin Centennial, the New York Academy of Sciences gave a large bronze bust of Charles Darwin to the American Museum of Natural History. Created by the well-known sculptor, William Couper, the bust was placed on its tall granite pedestal at the entrance at the newly designated exhibition hall, the Charles Darwin Hall of Invertebrate Zoology. Later that year, the American Museum ordered a bronze copy of the bust and presented it to Christ's College, in Cambridge, England at the British Darwinian celebration. In 1935, Victor Von Hagen requested a plaster copy of the bust for a monument he was erecting on San Cristóbal in the Galapagos Islands to celebrate Darwin's arrival in the Galapagos. During 1960, the American Museum of Natural History returned the original bronze bust to the New York Academy of Science, where it is now on display at its headquarters in New York City. To celebrate the Darwin bicentennial, the National Academy of Sciences recreated the bust in a computer-generated copy for display at their Washington, DC headquarters.
\end{abstract}

Keywords Charles Darwin - American Museum of Natural History - Darwin Bust · New York Academy of Sciences .

William Couper V Victor Wolkgang von Hagen - Galapagos · Darwin exhibitions · Christ's College 1909 Darwin Centennial

\section{Discussion}

In 1899, the American Museum of Natural History (AMNH) completed its striking red granite facade along

\section{S. Horenstein $(\bowtie)$}

American Museum of Natural History,

Central park West at 79th Street,

New York, NY 10034, USA

e-mail: horenst@amnh.org
West 77 th Street with the addition of its southeastern section. The museum's archives are mute concerning how the new space was used then, but its 1903 annual report says that specimens for the Synoptic Hall of Invertebrates had been obtained and installed in the exhibit space (American Museum of Natural History 1904). In 1908, the council of the New York Academy of Sciences (NYAS) proposed that the 100th anniversary of Charles Darwin's birth and the 50th anniversary of the publication of On the Origin of Species be celebrated appropriately the following year on February 12, 1909 (Anonymous 1908). They planned to have addresses delivered by the members of the Academy "setting forth Darwin's achievements in different departments of science, and a bronze bust of Darwin is to be unveiled and presented to the American Museum of Natural History by the President of the Academy [Charles F. Cox (1846-1912)] and accepted by the president of the museum [Henry Fairfield Osborn (1859-1935)]." The celebration, a collaboration between two prestigious New York intellectual institutions, was to include "an exhibition at the museum of Darwiniana and objects illustrating Darwin's theory of evolution through natural selection and his work in botanical, zoological and geological research." (Anonymous 1908). A memorial committee of 27 scientists from several institutions chaired by E.O. Hovey (1862-1924), Recording Secretary of the Academy, was appointed to make all the arrangements for the celebration (Anonymous 1909c; Fig. 1). Hovey is well known to New York City mineral specimencollecting enthusiasts for his mineral discoveries in various parts of the city and numerous other geological investigations (Betts 1909).

As planned, on February 12, 1909, the museum hosted the celebration sponsored by the Academy and attended by numerous dignitaries and scientists from around the country (Fig. 2). Although this date coincided with the birth of Abraham Lincoln, for whom there were also numerous 
The New York Academy of Sciences

invites you to attend its

exercises commemorating the

One Hundredth Anniversary of the Birth of

Charles Darwin

and the

Fiftieth Anniversary of the Publication of

"The Origin of Species"

American Museum of Natural History

Central Park, West, and Seventy-seventh Street

February the twelfth, nineteen hundred. nine at three o'clock p. m.

Fig. 1 Invitation to 1909 celebration, from Hovey (1909)

celebrations nationwide, Darwin was not forgotten. About 300 people attended the festivities at the AMNH in the Synoptic Hall (Anonymous 1909c). And New York City was not the only location hosting Darwin celebrations - there were celebrations in colleges, universities, and many scientific institutions in various parts of the United States including Columbia University, Cornell University, University of Illinois, University of Chicago, and the Academy of Natural Sciences of Philadelphia (Osborn 1909). Incidentally, the coincidence of Darwin's birth with that of Abraham Lincoln was a theme raised in many of the speeches portraying "several parallels in the personal character of these two great men: their simplicity, unconsciousness of power, abhorrence of slavery, clearness of expression, singleness of purpose,"

\section{Programme}

Presentation to the

American Museum of Natural History

of a

\section{Bronze Bust of Darwin}

\author{
By Charles Finney Cox \\ President of the New York Academy of Sciences \\ Acceptance on behalf of \\ the Trustees of the Museum \\ By Henry Fairfield Osborn \\ President of the American Museum of Natural History \\ Addresses
DARWIN AND GEOLOGY
By John James Stevenson \\ DARWIN AND BOTANY \\ By Nathaniel LoRd Britton \\ DARWIN AND ZOÖLOGY \\ By Hermon Carey Bumpus
}

Fig. 2 Schedule of events of 1909 celebration, from Hovey (1909) and honoring Darwin as "the emancipator of human thought, Lincoln as the emancipator of the negro race" (Anonymous 1909b; Osborn 1909).

For the occasion, the NYAS commissioned a well-known sculptor, William Couper (1853-1942), to create a twice life-size, 32- by 40-inch, 300-pound bronze bust of Charles Darwin (1809-1882) based mainly on original photographs in Cox's private collection (Figs. 3, 4, and 5). This portrait in the round was presented to the museum for installation at the entrance of the Synoptic Hall, rededicated upon the occasion as the Darwin Hall of Invertebrate Zoology (Osborn 1909; Browne 2009, page 554). Charles F. Cox opened the meeting with a sketch of Darwin's life and closed with the presentation of the "bronze portrait bust" mounted on a polished pedestal of the red granite of which

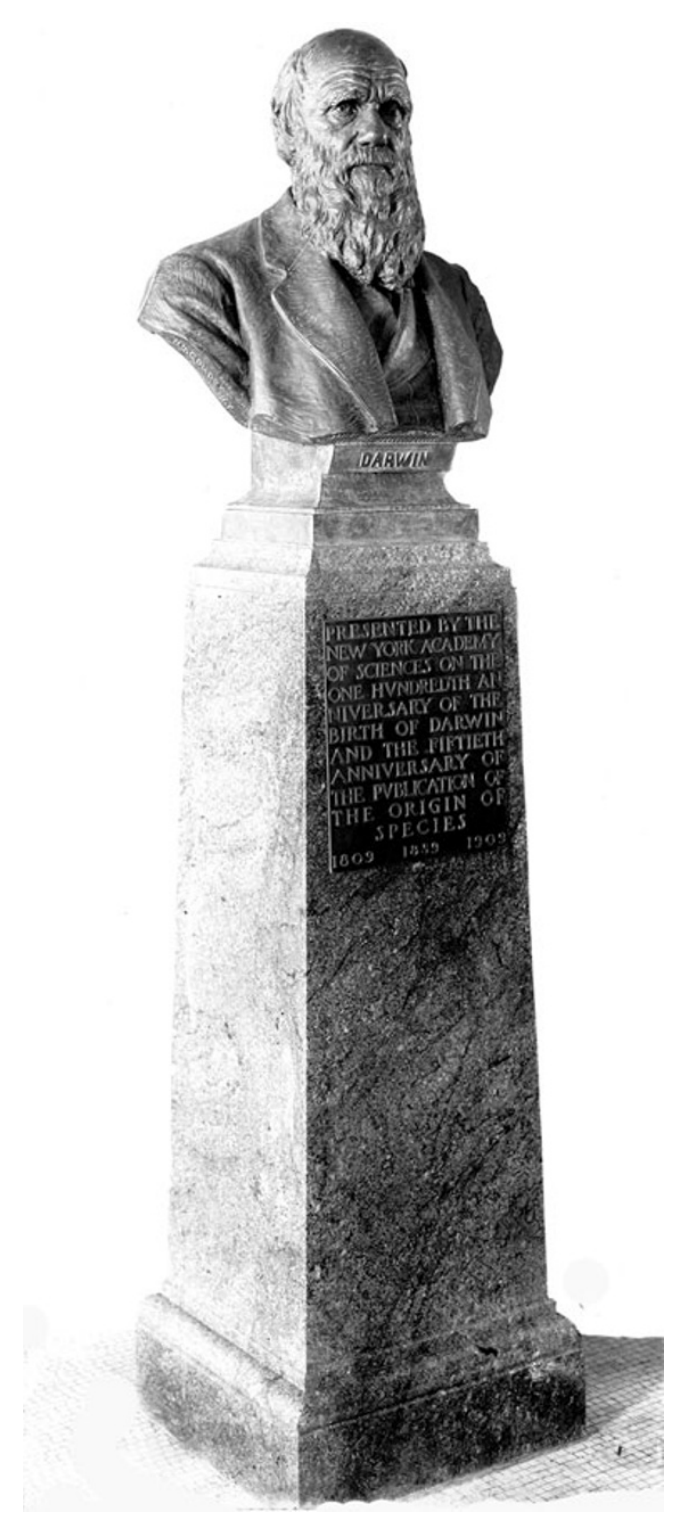

Fig. 3 Original pedestal and bust, 1909, the AMNH library image 


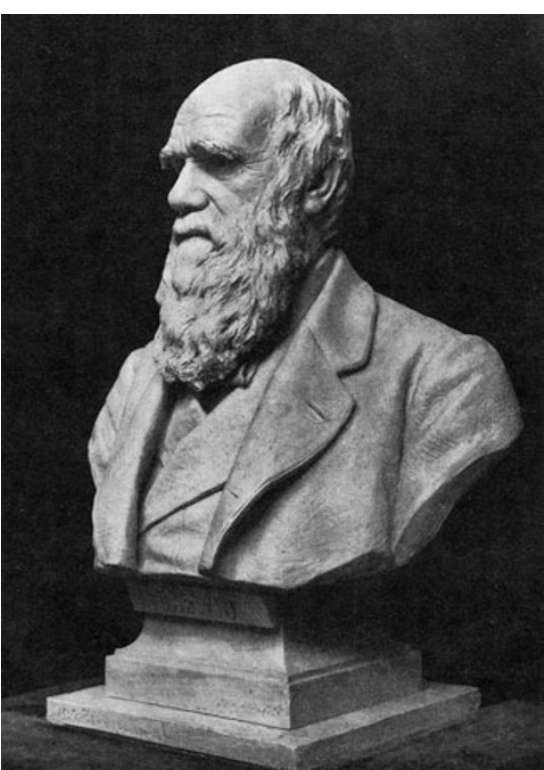

Fig. 4 Original bust, 1909, from Hovey (1909)

the museum is built (most likely Picton Island granite from the Thousand Islands in New York State), with a bronze tablet inscribed: "PRESENTED BY THE NEW YORK ACADEMY OF SCIENCES ON THE ONE HUNDRETH ANNIVERSARY OF THE BIRTH OF DARWIN AND THE FIFTIETH ANNIVERSARY OF THE PUBLICATION OF THE ORIGIN OF SPECIES 18091859 1909" (Fig. 6). In addition to the bust, there were two bronze plaques on either side of the entry to the hall proclaiming the "Darwin Hall of Invertebrate Zoology, Feb.12, 1909" (Anonymous 1909a; c) (Fig. 7).

To pay for the sculpture and event, the NYAS committee raised \$1,750 from 151 subscribers (Hovey 1909).

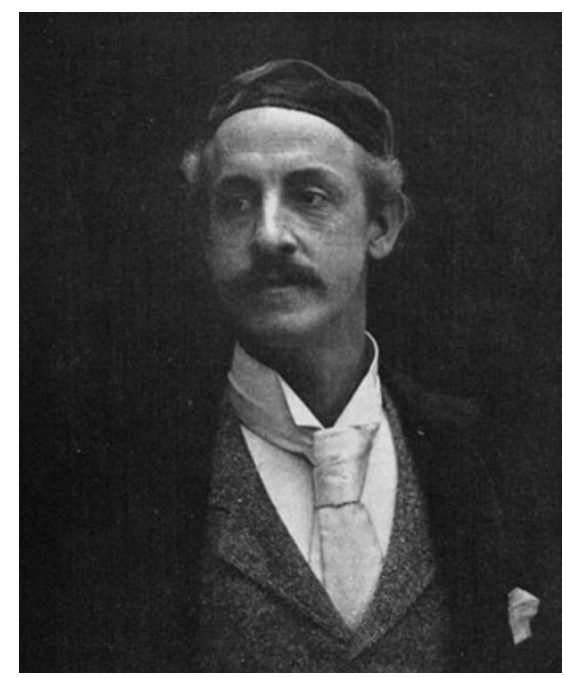

Fig. 5 Sculptor William Couper, from Anonymous (1907)
President Osborn closed the oratorical part of the celebration by announcing that, in order to further cement the name and spirit of Darwin with the museum, the trustees unanimously voted to rename this hall the Darwin Hall of Invertebrate Zoology. When all the speeches were given, the guests adjourned to the adjacent Hall of American Forestry where a special exhibition had been arranged to illustrate the principles brought out in Darwin's writings. In 15 alcoves of the hall, there were exhibits of each of the great principles and subjects treated by Darwin. Included was a temporary exhibit of first editions of all Darwin's publications, a series of portraits and autographed letters, and a sampling of photographs of Darwin's contemporaries, chiefly from the unique private collection of Charles F. Cox (Hovey 1909).

It may surprise some readers that the Darwin Celebration, organized by the NYAS (Darwin was made an honorary member in 1879), actually took place at the AMNH, but there is an underlying basis for it. In the late nineteenth century, many of the city's scientific organizations and societies organized themselves into a cooperative approach to work together, an endeavor led by the NYAS, to promote science in the city. As a result, in 1891 this network of groups formed the Scientific Alliance of New York. They created a cohesive policy to make the city a preeminent center of science and popularize it at a new building accommodating offices, lecture, and exhibition spaces modeled upon similar European endeavors (Sloan 1989). However, in 1901, Hermon C. Bumpus (1862-1943) - whose primary focus was public education - became the new director of the AMNH, thus moving away from the scientific research the museum was known for. Instead, he offered free museum space to the Scientific Alliance for executive meetings, and a number of scientific societies occupied museum rooms for their public meetings at a nominal charge and created independent exhibits at the museum that benefitted Bumpus' outreach priorities in public education. The formal existence of the Scientific Alliance terminated in April, 1907 "when all objectives sought were obtained" except for the building, which in reality, the AMNH had already provided. Charles F. Cox was president of both the Council of the Alliance and of the NYAS. Although the alliance dissolved, some of the former member organizations continued to hold meetings at the museum, and the trustees of NYAS continued to hold meetings at the AMNH. Many of the staff members of one society were members of the other organizations, sharing leadership and mutual support. Thus, in this spirit of cooperation, the 1909 Darwin Celebrations at the AMNH were not out of character (Baatz 1990).

In 1912, Cox's collection of Darwiniana was purchased by the New York Botanical Garden "as a permanent memorial of the late Charles Finney Cox, for many years Treasurer of the Garden and one of the original incorporators." Funds were raised from 27 members of The Garden Corporation and other 


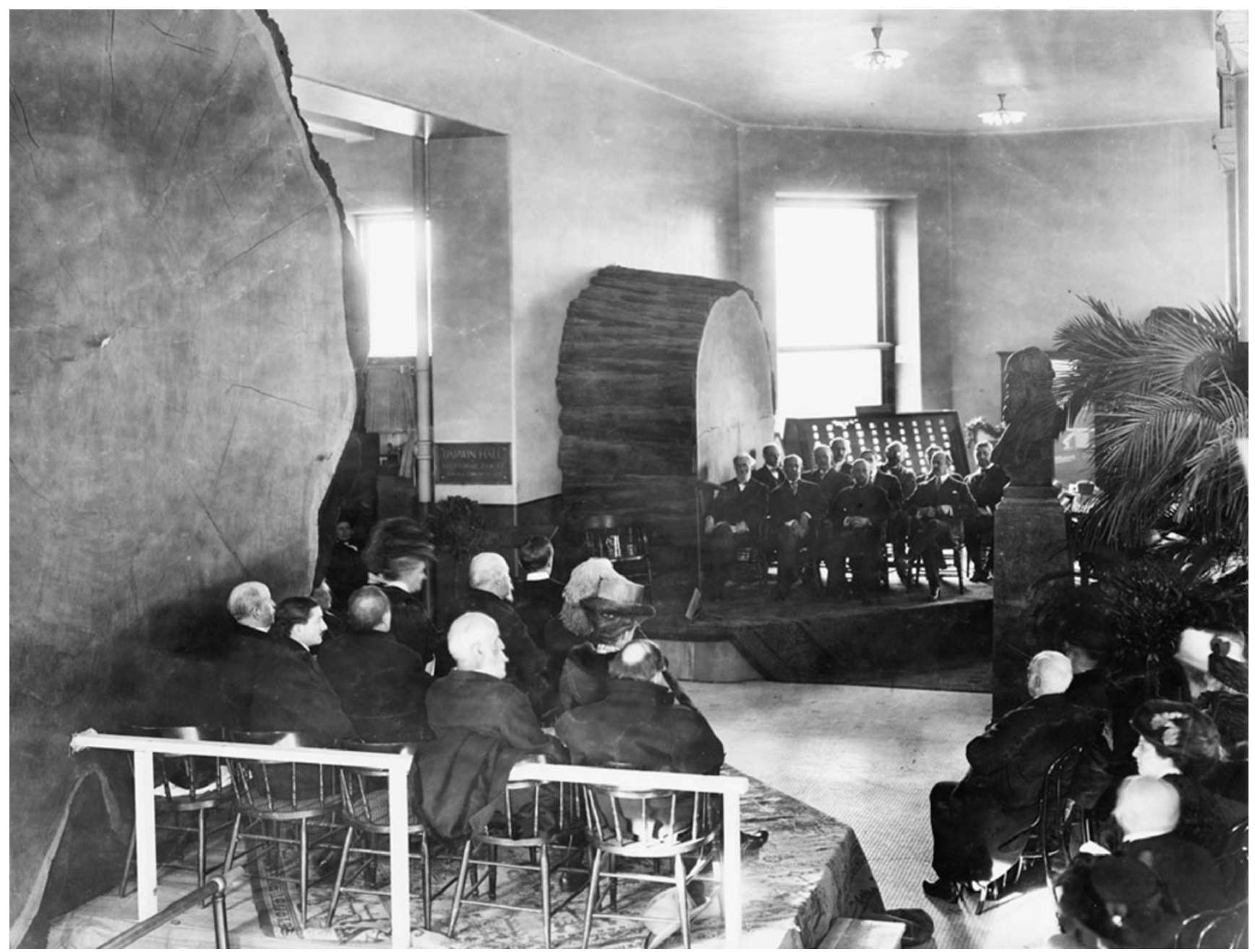

Fig. 6 Some of the 1909 centennial celebration participants at the American Museum of Natural History. Darwin, center right, looks toward the entrance of the Darwin Hall, the AMNH library image

friends to purchase the 236 items in his collection for $\$ 5,000$ (Sinon 2011), the catalog of which was published in the Journal of the New York Botanical Garden (Barnhart 1913).

The March, 1909 issue of the American Museum Journal contained a cover image of the bust as well as articles presented at Darwin's tribute (Anonymous 1909c). "The bust is pronounced by those who knew Darwin personally, and by his sons in England, who have seen photographs of the clay model, the best portrait in the round of the great naturalist ever made." (Hovey 1909). It was said that Couper based his work on "photographs taken when Darwin was fifty years old, at the time of the publication of the Origin of Species" (Anonymous 1909c).

William Couper was not unknown to the museum. He sculpted ten busts that were placed in wall niches (no longer visible) around the 77th Street foyer (originally Memorial Hall). The busts represented ten of the men considered foremost in the advancement of science in
America: Benjamin Franklin, Alexander von Humboldt, John James Audubon, John Torrey, Joseph Henry, Louis Agassiz, James Dwight Dana, Spencer Fullerton Baird, Joseph Leidy, and Edward Drinker Cope - and added later, Commander Peary. The busts were donated to the museum by Morris K. Jessup (1830-1908), a founder, trustee and president of the museum for 27 years (Anonymous 1907; Pindar et al. 1917).

Henry Fairfield Osborn, the museum's president, planned to attend the great celebration of Darwin's Centennial in Britain later the same year, June 23 to June 25 , and inquired of the president of the NYAS for permission to make a copy of the bust, to be presented to Christ's College, Darwin's alma mater (AMNH archives 1909, March 17, Hovey to Osborn). Osborn was informed by C.F. Cox that "The Darwin bust is now the property of the Museum, and the Museum is at liberty to do what it deems best about allowing, or procuring, replicas to be made." Cox also added that he would ask Couper what a replica would cost. "I do not see 
Fig. 7 Map of AMNH first floor exhibit halls showing location of the Darwin Hall, from 1939

Museum Guide

\section{FIRST FLOOR}

81 sr STREET

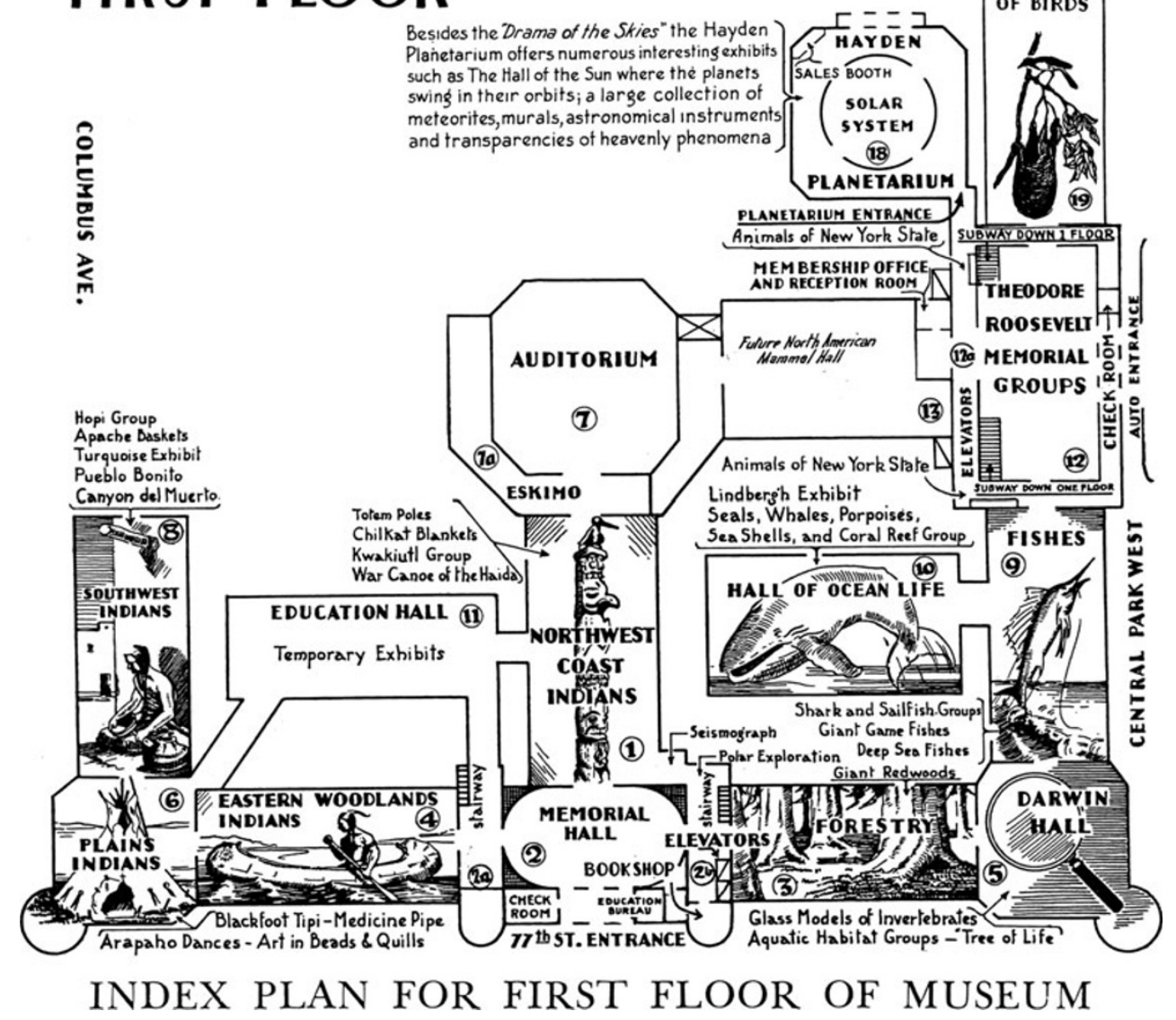

how it could be made for much less than the cost of the original bust (\$1000) since the clay model has been destroyed" (AMNH archives 1909, March 22, Cox to Osborn). Couper had a second bust made in time for the Museum to present it at the Darwin celebration in Britain. "With regard to the price: as the bust is a very large one, and the cost of casting etc. considerable it will amount to $\$ 1000.00$. This price should not be compared to the original cost - as I only charged half price. In other words, you will be getting two heroic busts for the same price others pay for one." (AMNH archives 1909, March 25, Couper to Bumpus).

AMNH Director Hermon C. Bumpus sent invitational letters to educational and scientific institutions throughout the country inviting delegate members to take part in the ceremonies in Britain. It was also an opportunity to request funds to pay for the bust. Each letter to the delegates states that the bust will be presented to Christ's College and "if you are in favor of such presentation send a note stating the amount of your subscription" (AMNH archives 1909, May 4 , Bumpus to all delegates). Contributions ranged from $\$ 15$ to $\$ 50$, but it seems most gave $\$ 50$. However, it should be noted that many of the delegates had to provide the money privately because their institutions did not allot funds for this particular activity or were not willing to support it. And even though some of the individuals were representing their institution, they had to pay their own expenses. "Dear Doctor Bumpus: I have your letter of May 4, and am thoroughly in sympathy with the movement to present to Christ's College, Cambridge, a replica of the bust of Darwin. I enclose a voucher and check to your order for Fifty Dollars, as the subscription of the Smithsonian Institution for this purpose" (AMNH archives 1909, May 8, Walcott to Bumpus). Charles D. Walcott (1850-1927) was the secretary of the Smithsonian Institution. In contrast Robert S. Woodward (1849-1924), president of Carnegie Institution, Washington D.C. wrote "I beg to state that I may not ask our Institution to contribute to the very worthy project of presenting to Christ's College, Cambridge a bronze copy of the capital bust of Darwin... The demand for such contributions from the Institution is so great that if we were to once give way to them they would speedily defeat its primary purpose, namely, the prosecution of research...I am to represent the Institution at the Cambridge function at my own expense, with full approval of the Institution's attitude concerning this matter," and "I shall be glad to contribute personally to the fund and I hereby offer you and your Committee \$50" (AMNH archives 1909, May 10, 
Woodward to Bumpus). These funds were raised to pay Couper for the duplicate sculpture, its transportation, and erection. Individuals and institutions who contributed toward defraying the cost of the gift of $\$ 1,000$ included Alexander Agassiz, Charles Davenport, Henry Fairfield Osborn, Research Club of the University of Michigan, University of Chicago, Cornell University, Philadelphia Academy of Sciences, Carnegie Institute, and the Brooklyn Institute of Arts and Sciences (Anonymous 1909d).

Osborn arrived in Britain with a 30-member contingent, part of the group of 250 scientists from 167 countries and 68 British institutions (Anonymous 1909f). Marsha Richmond, in her wide-ranging examination of the 1909 Darwin Celebration asks: "Why did scientists and layman the world over seek to honor the memory of a man who had been dead for scarcely twenty-five years?" Judging from the voluminous writings on Darwin and Darwinism that began appearing in 1908 and continued unabated throughout 1910, it was largely in recognition of the enormous influence the theory of evolution had on science and, through its application to sociopolitical thought, on society at large. She writes that the delegates sought not only to honor Darwin as a revolutionary scientist and cultural hero but also to use the occasion to examine the underpinnings of the evolution theory in the wake of a series of new developments. Her in-depth description and examination of these far-ranging topics and others will not be discussed here but is highly recommended for further reading (Richmond 2006; Anonymous 1909e).

On the afternoon of June 23, at a tea party at Christ's College where Darwin was a student, Osborn and the American delegation presented the bust to Christ's College as a memorial of their visit, along with "an extensive exhibition of portraits, manuscripts and other objects." Osborn hoped that the portrait bust would convey to future generations of Cambridge students some impression of the rugged simplicity as well as the intellectual grandeur of the man they revered and honored (Anonymous 1909d; f). For a complete catalog of the exhibits see: "1909: The First Darwin Century" (http://darwin-online.org.uk/1909.html).

Prior to the event, Bumpus and Osborn sent plans showing the desired dimension and design of the pedestal, but it did not meet with approval from Arthur Shipley (1861-1927). At the time, Arthur Shipley was the secretary to Cambridge Museums and eventually became vicechancellor of the University of Cambridge. After Bumpus inspected the bust, he told Osborn he was pleased with the results. They also discussed the "difficulties connected with the preparation of the pedestal so we both feel that it would be best to send the bust immediately to you [Shipley] by express." Bumpus essentially told Shipley, "place it where you like and the form of the pedestal can be changed to suit your wishes, and if a pedestal would not be appropriate place it in a niche" (AMNH archives 1909, May 27,
Bumpus to Shipley). This happened because the pedestal design sent to Shipley was too tall and would have to be a "couple of inches shorter" than asked for, so that "the total height will correspond with our bust of Milton" (AMNH archives 1909, May 11, Shipley to Bumpus), but then on May 12 Shipley wrote, "in fact, it would be nearly $21 / 2$ feet taller" than the Milton bust which "it would overtop" especially "since it would stand opposite it" (AMNH archives 1909, May 12, Shipley to Bumpus). Incidentally, Shipley lamented in one of his letters that: "I think I once saw Darwin in the street, but to my sorrow I have never been quite sure." (AMNH archives 1909, April 5, Shipley to Bumpus).

Two months after his return to the museum, Osborn wrote to Couper to tell him about the event: "I have been intending to write to you regarding the Darwin Bronze, which was very gratefully accepted by the authorities of Christ's College...Unfortunately, it was exhibited in a very small room with other memorabilia of life size, and its heroic size threw it somewhat out of proportion. Sir George Darwin said that he regarded it as a very good likeness but Professor Francis Darwin was rather reserved in his opinion. The general opinion seemed to be that it ranked with the best of the portrait busts of Darwin. The occasion, however, was such a hurried one, and there were so many events crowding in upon each other, that I await more mature judgment [from Darwin], which I am quite sure will be very favorable" (AMNH 1909, August 30, Osborn to Couper). Couper took Francis Darwin's reservations in good humor replying to Osborn that "I am in hopes that as soon as Prof. Francis Darwin becomes used to seeing his father's head so large, he will feel differently about it" (AMNH 1909, September 2, Couper to Osborn).

However, when we look back at the correspondence in 1908 related to the creation of the bust, we find that even then Francis Darwin's reaction at the time was somewhat equivocal. C.F. Cox wrote to Francis Darwin that one of the features of the Darwin anniversary celebration of his father will be "the presentation of a bust of Mr. Darwin in marble or bronze to the American Museum of Natural History." He asked for "suitable material" to aid the artist including a cast of a "bust made in 1869 by Mr. Woolner which appears to be the only 'portrait in the round' that was ever made directly from Mr. Darwin's features and which I understand proved to be quite satisfactory to his family." The purpose of the cast was to furnish "measurements and proportions which cannot be satisfactorily obtained from photographs" (NYBG archives 1908, March 6, Cox to Darwin). On March 15, 1908, Francis Darwin replied to Cox: The Woolner bust "was never liked by us. I showed it a year or so ago to Gilbert, the well-known sculptor who considered it technically very bad. No cast has ever been made of it." However, "I think your best plan would be to get a cast of the bust of which I send a photograph...I have 
never seen the bust but judging from the photograph it is a good portrait and a dignified bit of work...I have no idea whether Lehr is still living, the bust must have been made quite 20 years ago. I have not looked at this photograph for many years, and now I see how good it is. I wish I had a cast of the bust myself." (NYBG archives 1908, March 15, Darwin to Cox).

On May 20, 1908, C.F. Cox wrote to Francis Darwin that "William Couper, the artist, has finished the clay model of the bust, and I send you herein three photographs of it...As far as I can judge the artist has been successful in making a life-like and impressive portrait but of course he has labored under the disadvantage of being obliged to work from photographs...that had been taken from life and the artist conscientiously endeavored to evolve from them the truthful representation of Mr. Darwin's features. We shall feel greatly pleased if it appears to you that this object has been accomplished" (NYBG archives 1908, May 20, Cox to Darwin).

A few weeks later, Francis Darwin replied: "I think the bust of my father is good on the whole. The profile view of it is especially so, \& it was only after looking at it for a few days that I came to the conclusion that the nose is too long $\&$ indeed the whole face is too much elongated. I imagine that this can hardly be altered now? Probably any attempt might interfere with the dignity $\&$ unity it seems to possess. I should say that it is as satisfactory a portrait as you are likely to get" (NYBG archives 1908, June 16, Darwin to Cox).

Defending his work, Couper wrote to Cox responding to the criticism about the nose length and elongated face saying the photographic views altered the actual features of the bust. He also remarked that "You will recall the front view of Mr. Darwin was taken very late in life and his face appeared so full it seemed to lack character that was shown in the photograph we both liked so much...but I used that photo (the front view) to govern me in the widths of the forms that composed his head earlier in life...I trust that the character of the head will hold its own when placed in the museum which is not a most favorable light" (NYBG archives 1908, July 21, Couper to Cox). This letter also brings into question whether the bust really represented Darwin at age 50 or rather somewhat older. In addition, the reader can verify the age issue by simply searching Darwin images on Google which will reveal that the bust of Darwin depicts him as older than 50 years of age.

Prior to the celebrations in Britain, the copy destined for Christ's College was put on exhibit on May 25, 1909 in the window of the Gorham Manufacturing Company Building, 390 Fifth Avenue (36th Street) in New York City, home of an internationally known silversmith and the owner of the foundry that cast the bust (Diamonstein-Spielvolgel 2005, page 384). Adrian A. Buck, a Gorham representative writes "to ask you if you would kindly permit us to exhibit in our window, the bronze bust of 'Darwin' by 'Couper', as we should like to exhibit so worthy a piece" (AMNH archives 1909, April 7, Buck to Bumpus; April 9, 1909, Bumpus to Buck; Anonymous 1909g). The architectural firm of McKim, Mead, and White had recently (1904-1906) completed the building of showrooms, offices, and workshops for Gorham. The building was designated a New York City landmark on December 15, 1998, although the lower floors have been highly modified for commercial use. The balconies and friezes of bronze were designed by Stanford White and cast by Gorham's artisans. Not only did Gorham cast the Darwin busts, they also cast James Earle Fraser's bronze equestrian statue of Theodore Roosevelt, dedicated in 1940, that stands in front of the main entrance of the AMNH on Central Park West (Gorham History, http://gorham1831.com/ misc/gorham_history.cfm).

Over the years, the Darwin Hall saw additions and changes, including the addition of materials from various curatorial expeditions-until November 1, 1948 when the hall was permanently closed in preparation for new exhibits.

The hall was not closed in 1940 as claimed by several sources (Richmond 2006; Woram 2010a; AMNH 1949). In addition, in the various museum guidebooks over the years, the name listing the hall varied, finally settling on "Darwin Hall of Evolution," first used in 1926. The best illustrations of the hall were published in the 1939 "Guide to the Museum" (Miner 1939) which states that "This hall is devoted chiefly to invertebrate biological principles, especially those concerned with the evolution of life. It is therefore dedicated to Charles Darwin." After the 1909 ceremonies, interest in Darwin's bust abruptly ends until the 1930s, at least in museum archives and media publicity.

In 1933, Victor Wolfgang von Hagen (1908-1985) an anthropologist, explorer, and writer of several acclaimed books, many about the people of South America, described plans to Charles Galton Darwin (1887-1962) to erect a memorial in two years in the Galapagos Islands "to the visit of the Beagle 100 years ago." Darwin replied: "As to the appropriate way to do it, I fear I have no suggestions." (YALE archives 1933, August 24, Darwin to von Hagen). Then on September 7, von Hagen wrote to the British Legation in Peru, eventually receiving the following response from His Majesty's Minister: "Thank you for your letter of September 7, 1933 telling me about your scheme to dedicate a memorial to Charles Darwin and to sail from Peru, sometime in early in 1935, for the Galapagos Islands (Ecuador) for the purpose in question. You kindly express your intention to invite a member of His Majesty's Legation in Peru to accompany your expedition." He added that it was too far in the future and to repeat the invitation closer to the time (YALE archives 1933, October 21, von Hagen to British Legation). And then in February, 1935 he wrote to Roy Chapman Andrews: "You will perhaps recall that in January of last year we discussed 
at tea in the home of Dr. Osborn, the Darwin Memorial Expedition... I have written to Dr. Murphy of my desire of having, if possible a cast made on the bust of Charles Darwin" and "that to add this to the bronze placques that we have had cast, containing thereon an inscription written by Maj. Leonard Darwin..." (AMNH archives 1935, February 4, Von Hagen to Andrews; Woram 2010a). Roy Chapman Andrews (1884-1960) was the vice-director of the AMNH.

Von Hagen wanted to erect a monument on Isla San Cristóbal Island on September 17, 1935, for the 100th anniversary of Darwin's visit to the island, his first stop in the Galapagos. "Permission to erect a memorial to Charles Darwin in the Galapagos Islands...has been granted...In addition to the scientific research station, a monolith will be erected on Chatham Island [San Cristóbal]...This monolith will bear commemorative bas reliefs on each of its four faces and will be topped by a replica of the bronze bust of Darwin now in the hall of biology of the American Museum of Natural History. Dedication of the memorial has been fixed for September 6." (Anonymous 1935, June 21). He wrote to Robert Cushman Murphy (1887-1973), an American Museum ornithologist, asking for a plaster cast of Couper's bronze bust (Woram 2010a).

At first, museum officials looked for a cast in the storage areas and if "none come to light in the Museum, please advise me what it would cost to make a cast from the bronze bust..." (AMNH archives 1935, February 26, Faunce to Clark. Wayne M. Faunce (1899-1987) was vice-director and executive secretary of the AMNH). Two casts were made by E. Gargani and Sons. Eugene Gargani (1867-1938) owned a foundry in Greenpoint, Brooklyn which he purchased in 1928 and operated until 1949. The museum received the casts on May 9, 1935, and one of them was shipped to von Hagen. He was billed \$60, but von Hagen's agents paid for the shipping to South America (AMNH archives 1935, May 9, Clark to Faunce). James L. Clark (1883-1969) was director of preparation and installation at the AMNH. The cast was used to create a mold for a poured concrete bust, to which bronze filings were added in the hope that they would give the bust a bronze-like patina after it was placed on its 15 -foot pedestal. The bust still remains there, although on what is now the grounds of an Ecuadorian Second Zone Naval Base (Woram 2005, 2010a). For two images of the Darwin Monument, 1935 and 1960, see http://www. galapagos.to/TEXTS/VONHAGEN1.HTM.

"Even from a distance one could see the bust on top of the lava pedestal, and I thought the masons had done quite well... but they had found a heart-shaped stone which they put into the centre of the monument and wrote thereon, in large conspicuous letters AURELIO BORRERO-MASON". This dedication completely dwarfed the name of Charles Darwin (von Hagen 1940, pages 171-172) on the accompanying plaque which was written by Leonard Darwin
(1850-1943), Darwin's last surviving son: "Charles Darwin, Landed on the Galapagos Islands in 1835 and his studies of the distribution of animals and plants led him for the first time to consider problems of organic evolution. Thus was started that revolution in thought on this subject which has since taken place - Erected September 17th 1935." Although the inscription was written earlier, Charles Galton Darwin wrote to von Hagen: "My uncle, Major L. Darwin has shown me correspondence you have been sending him. His advanced age makes it difficult to deal with such matters and he feels that he must reserve his energies for duties that cannot be avoided. Would you therefore in the future address all correspondence connected with our family to myself and I will endeavor to answer it to the best of my ability." (YALE archives 1935, June 29, Darwin to von Hagen).

Von Hagen undoubtedly played a role in saving the Galapagos fauna, but how important it was is open to interpretation. Certainly, his books raised awareness of the islands. Given the fact that the Galapagos played such an important part in Darwin's works, included herein is a brief description of the political turmoil and biological preservation movements that swirled around von Hagen and the Galapagos during his quest to establish the Darwin monument: On February 20, 1920, the United States Senate passed an unusual resolution calling for a treaty to protect North American birds that spent part of the year below the Rio Grande (Anonymous 1920). As a result, in the same year, Alexander Wetmore (1886-1978) an ornithologist with the U.S. Biological Survey and later the sixth secretary of the Smithsonian Institution (1945-1952), studied the birds in South America and concluded that no legislation would serve to preserve some of these birds. Because of his pessimism, U.S. officials did not press for a treaty; besides, it was not a politically favorable time for the U.S. due to chilly relations with several South American governments. However, relationships improved with the implementation of the Good Neighbor Policy of the 1930s. In 1930, the American Committee for International Wildlife Protection was created. One of its interests was the Galapagos Islands, whose flora and fauna faced growing danger of destruction. In 1934, the American Committee passed a formal resolution to establish a scientific research station in the Galapagos. Then in August, 1934 the Ecuadorian government declared that several Galapagos Islands were protected refuges for resident and migratory animal life.

In the meantime, von Hagen, who had tenuous connections with the Ecuadorian government, pursued his own quest. He evidently began to plan his memorial expedition in 1933, not only to place the monument to Darwin there but to also fund a research station with a warden, but his plans for the research station fell through for the lack of money. Not only was the American committee concerned about the political developments in Ecuador, they were suspicious about von Hagen and 


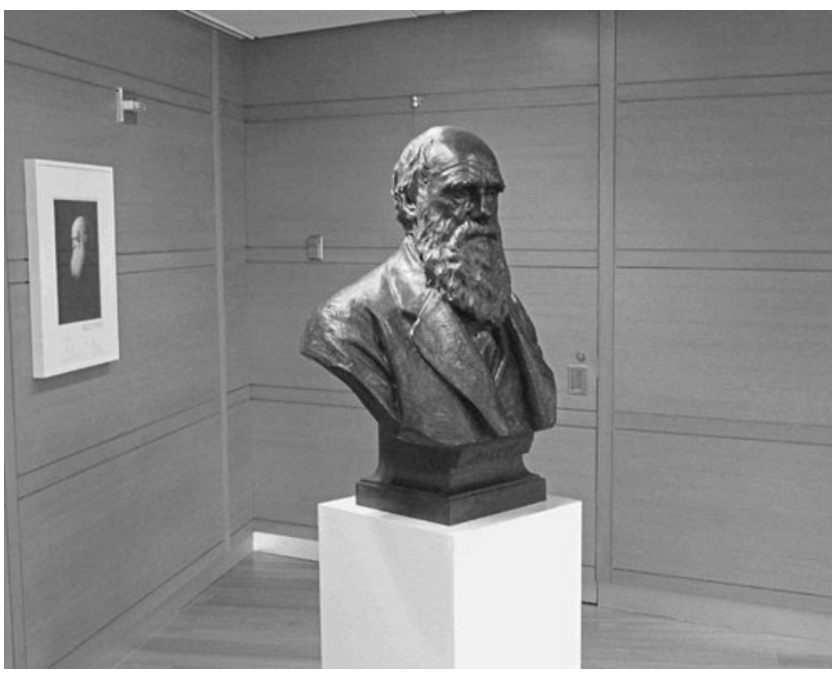

Fig. 8 Original Darwin bust, 2011, at the New York Academy of Science, photo: Sidney Horenstein

feared that his efforts were ultimately a moneymaking enterprise. Eventually, Ecuador government officials began denying that von Hagen had any official capacity, and the American committee began a campaign to discredit von Hagen. Students of environmental issues who wish to pursue further this interesting period in the attempt to "save" the Galapagos can read a full account of the period in Barrow's chapter 6, "The Latin American Turn" (Barrow 2009; see also Woram 2010b).

Recalling the second plaster bust mentioned previously, a clue to its whereabouts is contained in a 1937 letter to Dr. Leonard Covello, principal of Benjamin Franklin High School in Manhattan. "Would the High School be interested in acquiring a plaster copy of the bust of Benjamin Franklin on display in the Memorial Hall of the AMNH at the 77th Street entrance? We happen to have such a copy which will be destroyed unless suitable use can be found for it elsewhere. We also have similar copies of busts of Darwin, Agassiz, Dana and Humbolt..." (AMNH archives 1937, December 24, Faunce to Covello).

In 1957, an inventory of the busts in the Museum's possession no longer listed the plaster bust of Darwin (AMNH archives 1957, January 22, Miller to Kimball) nor was it on the 1960 extensive inventory of all paintings and busts in the report from the "Committee on the Evaluation of Disposable Material" which also indicated where the artwork was stored in the museum (AMNH archives 1960, June 7, Beneker to Oliver). The museum, anxious to dispose of this material, advertised on September 7 "a number of pieces of sculpture to any interested institution which will pay for the crating and transportation" (Anonymous 1960). The original Darwin bust was not listed in the advertisement. According to the June 7, 1960 list, the Darwin bust was to be saved for future use. However, on the October 27, 1960 and November 14, 1960

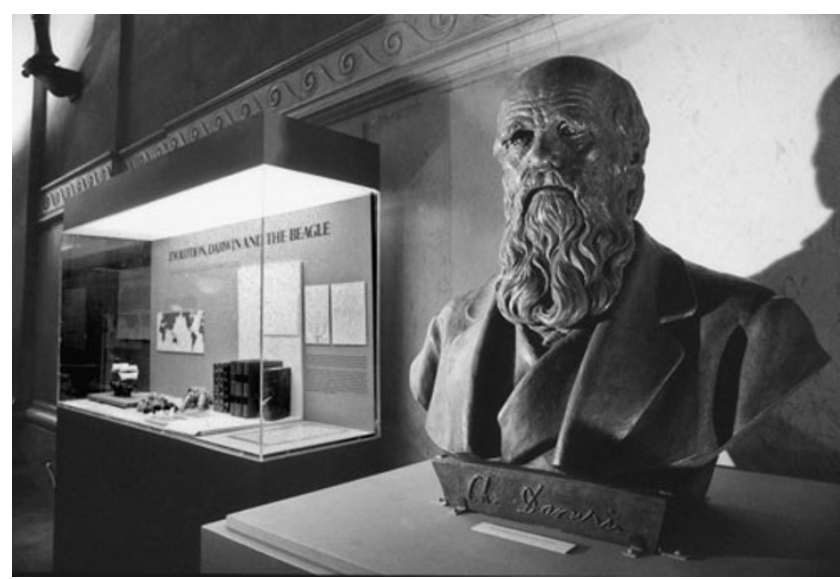

Fig. 9 Helmut Wimmer's Darwin bust in the 1981-1982 Darwin exhibit at the American Museum of Natural History, AMNH library image

inventory lists the original bronze bust of Darwin and pedestal were listed as being sent to the NYAS. There, the bust was placed in an outdoor patio in the academy's headquarters at East 63rd Street. In 2006, the academy moved to its new facilities at 7 World Trade Center where, in keeping with Charles Darwin's honorary membership in the organization (Fig. 8), the bust is placed atop a new pedestal adjacent to a wall displaying Darwin memorabilia.

To add some confusion to this sequence of events, an October 27, 1960 memo is a receipt for the Darwin bust and a marble pedestal sent to the NYAS. However, when the Darwin bust was brought to East 63rd Street, it was not with the original red granite pedestal but a shorter new one of Stony Creek Classic Granite. Perhaps it was for the same reason the pedestal design for the bronze copy destined to go the Christ's College was rejected; its height was not appropriate for the space. A clue to the original pedestal's

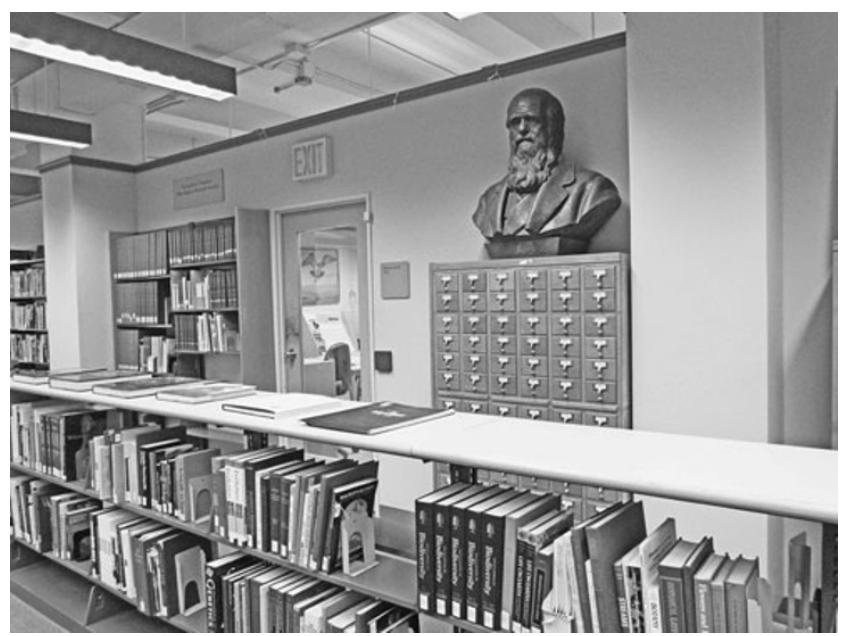

Fig. 10 Helmut Wimmer's Darwin bust in the AMNH library, photo: Sidney Horenstein 
whereabouts is contained in the following note: "A sculptress... is keen to have the two discarded pedestals... and she will make arrangements to have them carted away...one is marble with a crack and the other the pink granite one for the Darwin bust by Couper" (AMNH archives 1958, November 7, Kimball to Central Files).

After all of this, it may come as a surprise that there is still a bust of Darwin in the AMNH and for all to see, albeit an original plaster copy of the bronze bust with head and shoulders the same size but varying in some of the details. Placed on a pedestal of the library's old card catalog filing cabinet, he watches the coming and goings in the library's reading room as visitors study his publications. This plaster bust was created in 1973 by Helmut Karl Wimmer (19252006), principle artist in the museum's old Hayden Planetarium (Fig. 9). At this time, the circumstances for its creation are not known, nor do we know whether it was created from photographs or whether the sculptor had access to the original at the NYAS. Perhaps it was created for a new exhibit being installed at the time in the museum and was not used.

Much later in 1988, museum curators contemplating an exhibit about Darwin wrote to Director Thomas Nicholson (1923-1991) asking if he knew where the original Darwin bust was located. He responded that he was unable to trace it but speculated about its whereabouts, one of which was that it was returned to the NYAS. He also noted that he had Wimmer create the bust for Darwin's birthday but that was long before it was used in the 1981-1982 Darwin exhibit (AMNH archives 1988, October 14, Nicholson to Root).

Through the years, the AMNH mounted other exhibitions based on a variety of themes related to Charles Darwin. On November 24, 1959 on the 100th anniversary of the publication of On the Origin of Species the museum's exhibition of Darwiniana contained illustrations of his life and times and were labeled with his own writings (Anonymous 1959, November 22).

On February 4, 1969, an "Exhibit of the Month" featured the first edition of Darwin's On The Origin of Species together with a manuscript page of the book and a photograph of a bearded Darwin. (Anonymous 1969, February 4).

On December 28, 1981 to February 12, 1982 a new exhibition was created to mark the 150th anniversary of the sailing of H.M.S. Beagle from England, on December 27, 1831 (Shepard 1981). Included in the exhibit were the words and pictures of scientists who were among the forerunners of evolution-Linnaeus, Malthus, Lamarck, Spencer, and Lyell. It also featured a model of the Beagle and the Wimmer bust of Darwin as well as a copy of Darwin's diary and a map of the ship's travels (Fig. 10).

On November 7, 2005, a major exhibit on Darwin opened to great acclaim, a celebration of Darwin's life and his ideas which are the cornerstone of modern biology. The exhibit contained 400 artifacts, specimens, and documents and was designed to travel to various venues around the world in celebration of Darwin's bicentennial, and up to this time, it has been in Italy, Spain, Portugal, and Atlanta, Georgia. Niles Eldredge was the curator of the exhibit (Collins 2005). On March 23, 2011, the National Center for Science Education announced that Niles Eldredge was the recipient of the "Friend of Darwin" award for 2011.

Finally, in honor of the contributions made by Charles Darwin, the National Academy of Sciences commissioned a bronze replica of the Darwin bust based on the original Couper work to display in their Great Hall in Washington, D.C. The process used to create the reproduction for the academy combined traditional techniques with innovative digital technology. A virtual model was created by scanning the original sculpture in the NYAS. Using a computercontrolled milling process, a form was created from which the bronze was cast. This process reduces potential damage to the original and gives artisans more flexibility in refining the details of the final work (http://www.nyas.org/Publications/ Detail.aspx?cid=2bf71020-f95a-470c-a92b-90fde775cc0a).

Acknowledgments A number of individuals and institutions were helpful in creating this document including the librarians at Yale Libraries, Sterling Library of Manuscripts and Archives; Stephen Sinon, head archivist at the New York Botanical Garden; Matthew Clark, New York Academy of Sciences; and the librarians of the American Museum of Natural History, but especially Mai Qaraman, research services librarian, with special thanks, whose positive approach, intellectual curiosity, and expertise ferreted out the appropriate archival records and images which were indispensible for the completion of this project.

Notes During my weekly routine of looking at the new literature received by the museum's library, I would occasionally glance at Wimmer's bust of Darwin positioned atop the old card catalog. With the coming of the bicentennial, I began to wonder about who created the bust (which I found was signed) and why it was created long before the current Darwin celebration. Quickly, the pursuit led me to works of John Woram whose works listed above were the inspiration for this article.

One of the frustrating aspects of this project, like similar ones, is the fact that it may not be complete. Communication is a two-way street but only one way may be available in the records. Fortunately, some letter writers summarize, in one way or another, the reason for the response, but not always, but if one is lucky another institution may have the missing material. Unfortunately the archives of the New York Academy of Sciences that refer to the subject of this paper are no longer available.

\section{References}

American Museum of Natural History. Annual report for the year 1903. New York: Irving Press; 1904.

American Museum of Natural History. General guide to the exhibition halls of the American museum of natural history. Science guide no. 118. 5th ed. New York: Irving Press; 1949.

Anonymous. Memorials of men of science. Am Mus J. 1907;VII (2):19-21. 
Anonymous. The Darwin celebration of the New York academy of sciences. Science. 1908;28(727):790. December 4.

Anonymous. The Darwin celebration. Am Mus J. 1909a;IX(3):53-7. March.

Anonymous. Presentation of a bust of Darwin. Science. 1909b;29 (756):992. June 25.

Anonymous. The Darwin celebration at Cambridge. Nature. 1909c;81 (2070):7-14. July 1.

Anonymous. The Darwin celebration at Cambridge. Science. 1909d;30(759):80. July 16.

Anonymous. Bird treaties with other countries. Bird-Lore. 1920;22 (3):195-6. June 1

Anonymous. Memorial to Charles Darwin. Science. 1935;81 (2112):608. June 21.

Anonymous (1969) February 4, Darwin first edition is on display, The New York Times (www.nytimes.com)

Anonymous. Bust of Darwin on exhibition. The New York Times. 1909g May 26; (www.nytimes.com)

Anonymous. Darwin centennial and bust unveiling. The New York Times. 1909a Feb 13; www.nytimes.com

Anonymous. Darwin lecture at Columbia. The New York Times. 1909b Feb 13; www.nytimes.com

Anonymous. Darwin's evolution. The New York Times. 1959 Nov 24 (www.nytimes.com)

Anonymous. Sculptures offered at shipping costs. Museum News. 1960;39(1):7. Sep 7.

Baatz S. Knowledge, culture and science in the metropolis: The New York Academy of Science, 1817-1970. Annals of the NYAcad of Science. 1990;584:269.

Barnhart JH. Catalogue of the Cox collection of Darwiniana. J New York Bot Gard. 1913;XIV(157):2-29. January, 1913.

Barrow Jr MV. Nature's ghosts: confronting extinction from the age of Jefferson to the age of ecology. Chicago: University of Chicago Press; 2009.
Betts JH. The minerals of New York City. Rocks \& Minerals. 1909;84 (3):204-40.

Browne J. Looking at Darwin: portraits and the making of an icon. Isis. 2009;100:542-70.

Collins, G. An evolutionist's evolution; exhibit focuses on Darwin's life and ideas, not controversy. New York Times, 2005 Nov 7

Diamonstein-Spielvolgel B. The landmarks of New York. New York: The Monacelli Press; 2005.

Hovey EO. Darwin memorial celebration. Annals New York Academy of Sciences. 1909;19(1 (Pt. 1)):1-40.

Miner, RW. Exhibition Halls of the American Museum of Natural History. New York, American Museum of Natural History, 1939; 174.

Osborn HF. Darwin celebrations in the United States. Nature. 1909;80 (2055):72-3. March 18.

Pindar GN et al. Guide to the nature treasures of New York City. New York: Charles Scribner's Sons; 1917.

Richmond M. The 1909 Darwin celebration: reexamining evolution in the light of Mendel, mutation, and meiosis. Isis. 2006;97:44784.

Shepard RF. The fittest in going out guide. The New York Times. 1981 Dec 28

Sinon S. Archivist. New York Botanical Garden personal communication. 2011 Apr 27

Sloan D. Science in New York City, 1867-1907. Isis. 1980;71(1):3576.

Von Hagen VW. Ecuador the unknown. Oxford: Oxford University Press; 1940

Woram J. Charles Darwin slept here. Rockville: Rockville Press; 2005.

Woram J. Ecuador the unknown and the Galapagos revisited. 2010. Available from: http://www.galapgos.to/TEXTS/VONHAGEN. HTM

Woram J. Portraits in the round: busts of Charles Darwin. 2010. Available from http://www.galapgos.to/TEXTS/COUPER.HTM 